\title{
Genomic and phenotypic profiles of two Brazilian breast cancer cell lines derived from primary human tumors
}

\author{
NATÁSSIA C.R. CORRÊA ${ }^{1}$, HELLEN KUASNE ${ }^{2}$, JERUSA A.Q.A. FARIA ${ }^{1}$, CIÇA C.S. SEIXAS ${ }^{1}$, \\ IRIA G.D. SANTOS ${ }^{3}$, FRANCINE B. ABREU ${ }^{4}$, SUELY NONOGAKI ${ }^{5}$, RAFAEL M. ROCHA ${ }^{5}$, \\ GERLUZA APARECIDA BORGES SILVA ${ }^{3}$, HELENICE GOBBI ${ }^{6}$, SILVIA R. ROGATTO ${ }^{4,7}$, \\ ALFREDO M. GOES ${ }^{1}$ and DAWIDSON A. GOMES ${ }^{1}$ \\ ${ }^{1}$ Department of Biochemistry and Immunology, Federal University of Minas Gerais, Belo Horizonte; \\ ${ }^{2}$ Department of Biological Sciences, State University of Londrina, Londrina; ${ }^{3}$ Department of Morphology, \\ Federal University of Minas Gerais, Belo Horizonte; ${ }^{4}$ NeoGene Laboratory, CIPE; ${ }^{5}$ Department of Anatomic Pathology, \\ A.C. Camargo Hospital, São Paulo; ${ }^{6}$ Department of Anatomic Pathology, Federal University of Minas Gerais, \\ Belo Horizonte; ${ }^{7}$ Department of Urology, School of Medicine, Paulista State University, Botucatu, Brazil
}

Received September 25, 2012; Accepted November 14, 2012

DOI: $10.3892 /$ or.2013.2284

\begin{abstract}
Breast cancer is the most common type of cancer among women worldwide. Research using breast cancer cell lines derived from primary tumors may provide valuable additional knowledge regarding this type of cancer. Therefore, the aim of this study was to investigate the phenotypic profiles of MACL-1 and MGSO-3, the only Brazilian breast cancer cell lines available for comparative studies. We evaluated the presence of hormone receptors, proliferation, differentiation and stem cell markers, using immunohistochemical staining of the primary tumor, cultured cells and xenografts implanted in immunodeficient mice. We also investigated the ability of the cell lines to form colonies and copy number alterations by array comparative genomic hybridization. Histopathological analysis showed that the invasive primary tumor from which the MACL-1 cell line was derived, was a luminal A subtype carcinoma, while the ductal carcinoma in situ (DCIS) that gave rise to the MGSO-3 cell line was a HER2 subtype tumor, both showing different proliferation levels. The cell lines and the tumor xenografts in mice preserved their high proliferative potential, but did not maintain the expression of the other markers assessed. This shift in expression may be due to the selection of an 'establishment' phenotype in vitro. Whole-genome DNA evaluation showed a large amount of copy number alterations (CNAs) in the two cell lines. These findings render MACL-1 and MGSO-3 the first characterized Brazilian
\end{abstract}

Correspondence to: Professor Dawidson A. Gomes, Biological Sciences Institute, Department of Biochemistry and Immunology, Federal University of Minas Gerais, Bloco Q4-238, Av. Antônio Carlos 6627, 31270-901 Belo Horizonte, Minas Gerais, Brazil E-mail: dawidson@icb.ufmg.br

Key words: breast cancer, primary tumor, cell line, tumor xenograft, immunohistochemistry, array comparative genomic hybridization breast cancer cell lines to be potentially used for comparative research.

\section{Introduction}

Breast cancer is a leading cause of death worldwide and represents the primary cause of mortality among women in Brazil (1). Breast tumors are conventionally classified based on prognostic factors, including histological type and grade, proliferation index and angiolymphatic invasion. The St. Gallen Consensus, the American Society of Clinical Oncology (ASCO) and the College of American Pathologists (CAP) also state the evaluation of estrogen receptor (ER), progesterone receptor (PR) and human epidermal growth factor receptor 2 (HER2) status for the prognosis and recommendation of adjuvant therapy (2-4).

Although well-established as prognostic and diagnostic tools, information provided by classical pathological evaluation still fails to predict, with accuracy, the patient's clinical progression. Thus, the genetic and transcriptional diversity of tumor cells are receiving considerable attention, as they may represent the primary cause of unpredictable tumor behavior and the failure of certain currently used treatments. In their pioneering study, Perou et al (5), identified a correlation between histopathological findings and the gene expression profile of various types of breast tumor, correlating classic immunohistochemistry (IHC) and cDNA microarrays. Theirs and subsequent studies (6-8) defined novel molecular subtypes of breast tumors, including luminal A, luminal B, HER2, basal and, more recently, the claudin-low subtype (9).

Subsequently, using an experimental approach similar to that used in previous studies, Kao et al (10) applied molecular profile classification to known breast cancer cell lines. Many of the cell lines investigated (MCF-7 or MDA-MB-231) were obtained from metastatic tumors, and are frequently used as breast cancer models. However, metastasis-derived cells have already undergone crucial stages in tumor progression, including the development of invasive capability, cellular 
adhesion to other organism sites and adaptation to a new environment. Therefore, although widely used, these cell lines do not represent the cells present in primary tumors.

The use of breast cancer cell lines derived from primary tumors as in vitro models has rarely been reported and may offer relevant data regarding this type of cancer, increasing the knowledge provided by metastasis-derived cell research. To further understand breast cancer in its initial stages, we investigated the MACL-1 and MGSO-3 breast cancer cell lines previously derived from primary human tumors in our laboratory (11). Correa et al characterized these cells lines as authentic tumor and immortalized cell lines through serial passages, loss of contact inhibition, telomerase activity (to confirm immortalization), ability to assemble colonies on agar plates and formation of tumors in immunodeficient mice (11). Moreover, these cells present the differential expression of genes and surface molecules, such as $M U C 1$ and GAPDH (12), and resistance to $\gamma$-irradiation (13).

To gain better understanding of these cell lines, this study evaluated the phenotypic markers from the MACL-1 and MGSO-3 cell lines in comparison to primary tumors and xenograft implants in immunodeficient mice, developed from these cell lines using IHC. Additionally, copy number alterations (CNAs) were evaluated using array comparative genomic hybridization (aCGH). These findings render MACL-1 and MGSO-3 the first characterized breast cancer cell lines to potentially be used for comparative research with other established breast cancer cell lines.

\section{Materials and methods}

Cell culture. The MACL-1 and MGSO-3 cell lines were previously derived from breast tumor tissue in our laboratory [Correa et al (11)]. The cells were grown in Dulbecco's modified Eagle's medium (DMEM, Sigma-Aldrich, St. Louis, MO, USA) supplemented with $10 \%$ fetal bovine serum (FBS; Sigma-Aldrich) and penicillin/streptomycin (100 U/ml; Life Technologies, Carlsbad, CA, USA) at $37^{\circ} \mathrm{C}$ in an atmosphere of $5 \% \mathrm{CO}_{2}$.

Xenotransplants. Pathogen-free BALB/c.Cg-Foxn $1^{\text {nu/ }}$ AnNTacUnib mice (age, 6-8 weeks) were housed in filter-top cages, and sterile water and food were provided ad libitum. The manipulations were conducted aseptically inside a laminar flow hood. One million MACL-1 and MGSO-3 cells were diluted in phosphate buffer and injected subcutaneously between the scapulae of each animal, as described in our previous study (11). The mice were examined for tumor growth every 3 days. When the tumors reached $10 \mathrm{~mm}$ in size, the mice were sacrificed and the tumor was dissected for histological examination. Animal experiments were approved by the Animal Use Ethics Committee of the Federal University of Minas Gerais (Belo Horizonte, Brazil).

Histopathological analysis. Primary tumors were obtained from 2 breast cancer samples obtained from 2 patients (patients 1 and 2) who had presented at Santa Casa de Misericórdia Hospital in Belo Horizonte, Brazil. Samples were routinely processed, embedded in paraffin and $4-\mu \mathrm{m}$-thick sections were cut and stained with hematoxylin and eosin (H\&E) to evaluate tumor morphology and grade. To evaluate tumor xenografts, the animals were sacrificed and the tumors were excised and fixed in $4 \%$ buffered formaldehyde for 24-48 h. Tumor fragments were then rinsed with phosphate buffer, dehydrated in a series of graded ethanol washes and embedded in paraffin. To compare the MACL-1 and MGSO-3 cells grown in vitro with tumors grown in vivo and primary tumors, the cells were cultured in chamber slides (Lab-TekII, Thermo Fisher Scientific Inc., Waltham, MA, USA). Subsequent to attaining confluence, the cells were fixed with buffered formalin for 1-2 min, washed with phosphate buffer, and stored in this solution until immunohistochemical staining was performed. This study was approved by the institutional Human Ethics Committee (ETIC 03120203000).

Immunohistochemical analysis. Immunohistochemical analysis was performed using the antibodies shown in Table I (2,3,5,14-16). Sections were deparaffinized using xylene and rehydrated in a series of decreasing concentrations of ethanol solutions. Heat-induced epitope retrieval was then carried out in citrate buffer (sodium citrate, $10 \mathrm{mM}$; pH 6.0) in a pressure cooker for $4 \mathrm{~min}$ at full pressure. Subsequent to cooling, endogenous peroxidase was blocked using a $3 \%$ hydrogen peroxide solution for $20 \mathrm{~min}$. The slides were then washed with phosphate buffer solution (10 mM; pH 7.4) and incubated with primary antibodies for $20-30 \mathrm{~min}$ or overnight at $4^{\circ} \mathrm{C}$ and washed 3 times with phosphate buffer. The slides were subsequently incubated using the Advance HRP (Dako, Carpinteria, CA, USA) or MACH 4 Universal HRP-Polymer (Biocare Medical, Concord, CA, USA) detection systems, according to the respective manufacturer's instructions. The slides were washed 3 times with phosphate buffer and the colored reaction product was developed using 3,3-diaminobenzidine tetrahydrochloride (DAB; Dako) as a substrate for $1 \mathrm{~min}$, while nuclear contrast was achieved using Harris hematoxylin counterstaining. Paraffin sections from the original primary tumors and xenografts were examined using the same procedure. ER and PR staining were evaluated using the Allred scoring system (2). HER2 staining was evaluated as recommended by the CAP/ASCO guidelines (3). Ki-67 was evaluated as the percentage of staining. Qualitative analyses (positivity/negativity) were carried out for the remaining antibodies in the absence of any current official recommendations. Negative controls were obtained by omitting primary antibodies. Heat-induced epitope retrieval was omitted for cultured cells and sections stained for HER2 (clone CB11).

Clonogenic assay. Cell survival was measured using clonogenic assay (17). Briefly, 900 cells were seeded in $10-\mathrm{cm}^{2}$ plates and incubated for 10 days. Colonies were stained using a mixture of $6.0 \%$ glutaraldehyde and $0.5 \%$ crystal violet, and then rinsed with water. Colonies with $>50$ cells were counted as survivors. Surviving fractions were normalized by the plating efficiency of MDA-MB-231 cells. Statistical analysis was carried out using GraphPad Prism 5 software (GraphPad Software, Inc., La Jolla, CA, USA) using one-way ANOVA and Duncan's post-test. $\mathrm{P}<0.05$ was considered to indicate a statistically significant difference.

aCGH. Genomic DNA from MACL-1 and MGSO-3 cell lineages was obtained using SDS/proteinase $\mathrm{K}$ digestion, followed by 
Table I. Primary antibodies, clones, dilution ratios and sources used for immunohistochemical staining.

\begin{tabular}{|c|c|c|c|}
\hline Antibodies & Clone & Dilution & Source \\
\hline Estrogen receptor $\left(\mathrm{ER}^{\mathrm{a}}\right)$ & $6 \mathrm{~F} 11$ & $1: 100$ & Neomarkers \\
\hline Estrogen receptor $\left(\mathrm{ER}^{\mathrm{b}}\right)$ & SP1 & $1: 100$ & Neomarkers \\
\hline Progesterone receptor $\left(\mathrm{PR}^{\mathrm{a}}\right)$ & PgR 312 & $1: 200$ & Novocastra \\
\hline Progesterone receptor $\left(\mathrm{PR}^{\mathrm{b}}\right)$ & PgR 636 & $1: 400$ & Dako \\
\hline HER $2^{\mathrm{a}}$ & CB11 & $1: 200$ & Novocastra \\
\hline HER $2^{b}$ & Rabbit polyclonal & $1: 2,000$ & Dako \\
\hline Ki-67 & MIB-1 & $1: 800$ & Dako \\
\hline CD44 & F10-44-2 & $1: 40$ & Novocastra \\
\hline CD24 & SN3 & $1: 50$ & Neomarkers \\
\hline CD133 & Rabbit polyclonal & $1: 100$ & Abcam \\
\hline Cytokeratin 5 (CK5) & XM26 & $1: 300$ & Neomarkers \\
\hline EGFR & EGFR-25 & $1: 100$ & Novocastra \\
\hline
\end{tabular}

Detected using the ${ }^{\mathrm{a}} \mathrm{MACH} 4$ Universal HRP-Polymer and ${ }^{\mathrm{b}}$ Advance HRP detection systems.

Table II. Immunohistochemical profiles of the primary tumors of the patients (patients 1 and 2), cultured cell lines (MACL-1 and MGSO-3) and cell line-derived tumor xenografts.

\begin{tabular}{|c|c|c|c|c|c|c|}
\hline \multirow[b]{2}{*}{ Antibodies } & \multicolumn{2}{|c|}{ Patient } & \multicolumn{2}{|c|}{ Cultured cell line } & \multicolumn{2}{|c|}{ Tumor xenograft } \\
\hline & 1 & 2 & MACL-1 & MGSO-3 & MACL-1 & MGSO-3 \\
\hline ER & + & - & - & - & - & - \\
\hline PR & + & - & - & - & - & - \\
\hline HER 2 & - & + & - & - & - & - \\
\hline Ki-67 & + & + & + & + & + & + \\
\hline CD44 & - & - & - & - & - & - \\
\hline CD24 & - & + & - & - & - & - \\
\hline CD133 & - & - & - & - & - & - \\
\hline CK5 & - & - & - & - & - & - \\
\hline EGFR & - & - & - & - & - & - \\
\hline
\end{tabular}

phenol/chloroform extraction and ethanol precipitation (18) and treatment with $20 \mu \mathrm{g} / \mathrm{ml}$ RNase A (Sigma-Aldrich). CNAs were evaluated in the MACL-1 and MGSO-3 cell lines using the high-resolution SurePrint G3 Human CGH Microarray kit, 4x180K (Agilent Technologies, Santa Clara, CA, USA). A female genomic DNA control sample (Promega, Fitchburg, WI, USA) was used as the reference. Test and reference DNA were fluorescently labeled using the Agilent Genomic DNA Enzymatic Labeling kit (Agilent Technologies). Experiments were performed in duplicate by swapping dyes between the test and control samples to reduce analytic errors resulting from labeling and hybridization. Subsequent to slide scanning (Agilent DNA Scanner, at 5- $\mu \mathrm{m}$ resolution), image data were extracted and normalized using Feature Extraction 10.1.1.1 software (Agilent Technologies). The array-based CGH data were analyzed using the Nexus Copy Number software version 6.0 (BioDiscovery, Hawthorne, CA, USA) with a FASST2 segmentation algorithm, responsible for the detection of statistically significant CNAs, a sensitivity threshold of $1.00 \mathrm{E}-6,3$ consecutive probes, and a $\log _{2}$ $\leq-0.13$ and $\geq+0.3$ for the determination of a loss or gain region, respectively.

\section{Results and Discussion}

Immunohistochemistry. The breast tumor sample from patient 1 exhibited an invasive ductal carcinoma morphology that may be sub-classified as a luminal A subtype carcinoma (ER/PR-positive and HER2-negative) (Fig. 1). Tumors associated with this subtype are known to be less aggressive and have improved prognosis in patients (6). Moreover, the tumor from patient 1 had a low mitotic grade $(<25 \%)$, as demonstrated using H\&E-stained slides and Ki-67 staining.

Conversely, the breast tumor sample from patient 2 was considered to be a ductal carcinoma in situ (DCIS) and presented with a HER2 subtype profile, given that the tumor was negative for ER/PR staining and showed strong HER2 

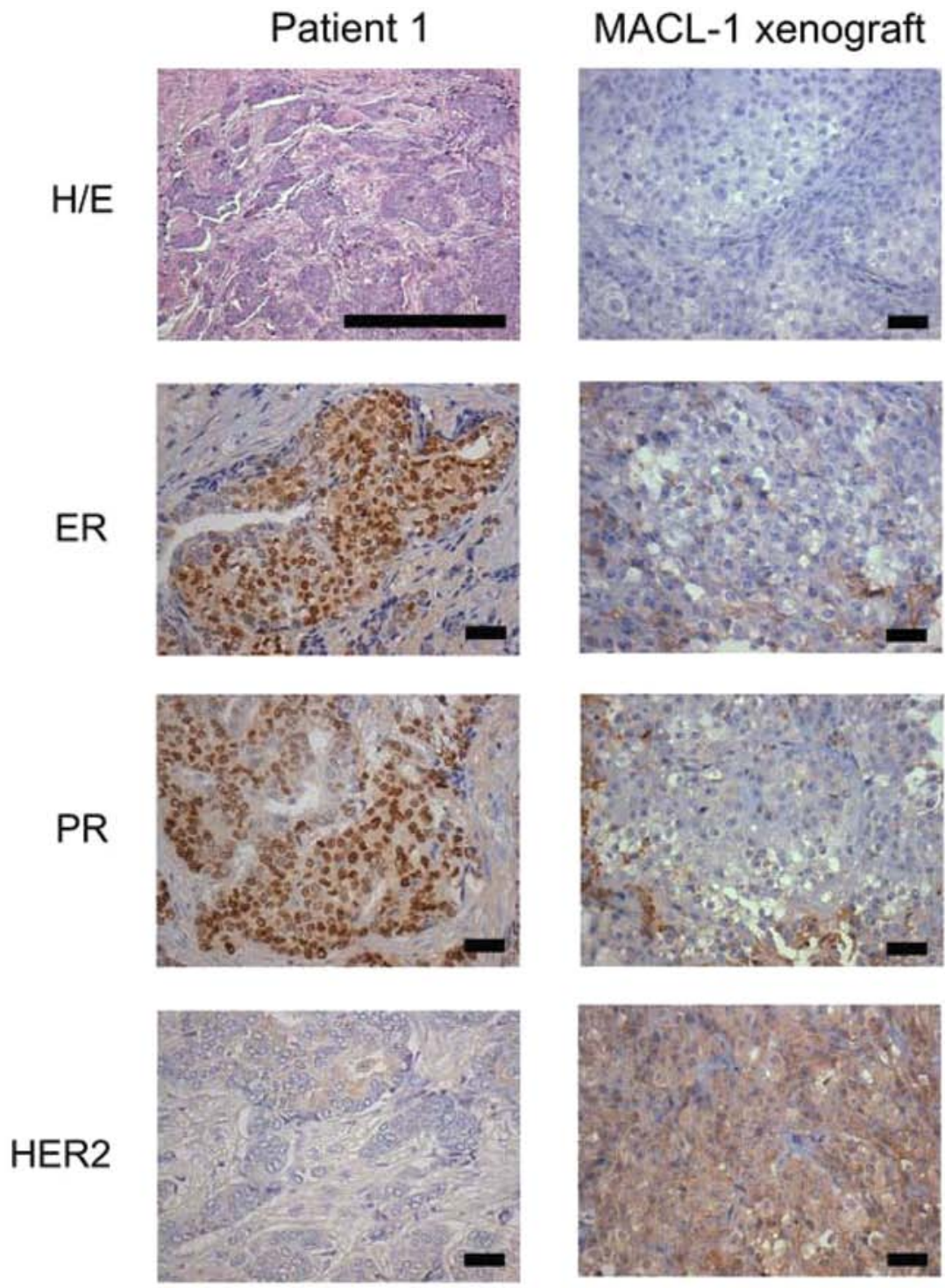

HER2
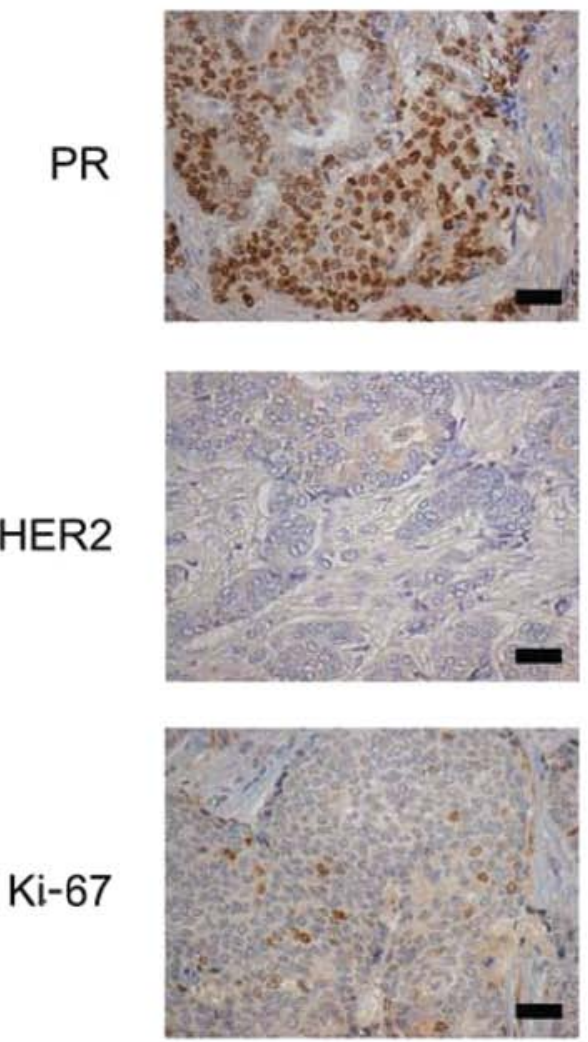

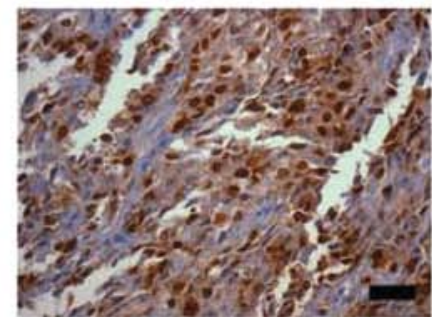

MACL-1cells
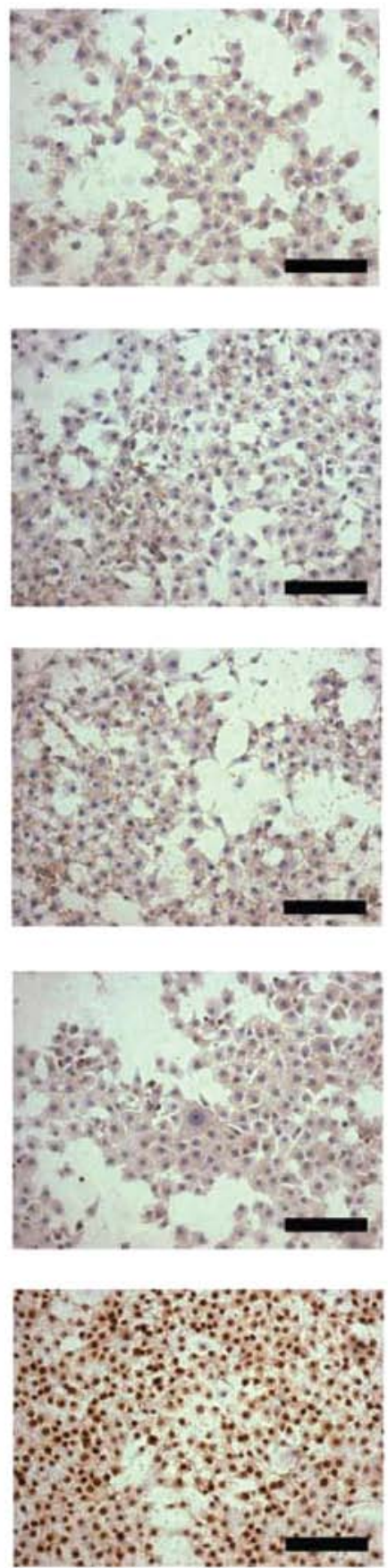

Figure 1. Immunohistochemical profiles of ER, PR, HER2 and Ki-67 markers in the tumor sample from patient 1 (Patient 1); MACL-1-derived tumor xenograft in immunodeficient mouse (MACL-1 xenograft) and MACL-1-cultured cell line (MACL-1 cells). Scale bar, $100 \mu \mathrm{m}$.

staining (3+) (Fig. 2). Breast tumors of the HER2 subtype have a worse prognosis and comprise some of the most aggressive tumors (6). Additionally, this primary tumor had a high mitotic index $(>25 \%)$, as demonstrated by H\&E and Ki-67-stained slides.

The tumor sample from patient 2 also showed marked CD24 staining, although MGSO-3 cultured cells and xenografts from these cells were not stained using this marker (Fig. 3). CD24 is a mucin-like adhesion molecule expressed at multiple stages of B-cell development. This protein increases metastatic potential in tumors since it is a ligand of P-selectin, an adhesion receptor of endothelial cells and platelets (19), and has been implicated as an indicator of worse survival prognosis in breast cancer patients (20). Reports that breast cancer stem cells have the CD $44^{+} / \mathrm{CD} 24$ - phenotype, as shown in the study by Al Hajj et al (15), are inconsistent with the metastatic role of CD24. Nonetheless, the metastasis process is biologically distinct from that of tumor growth in cancer stem cells, explaining the presence or absence of this marker at diverse stages of breast cancer progression (21).

CD24 staining of the primary tumor of patient 2 may be indicative of a carcinoma that, albeit non-invasive, is associ- 

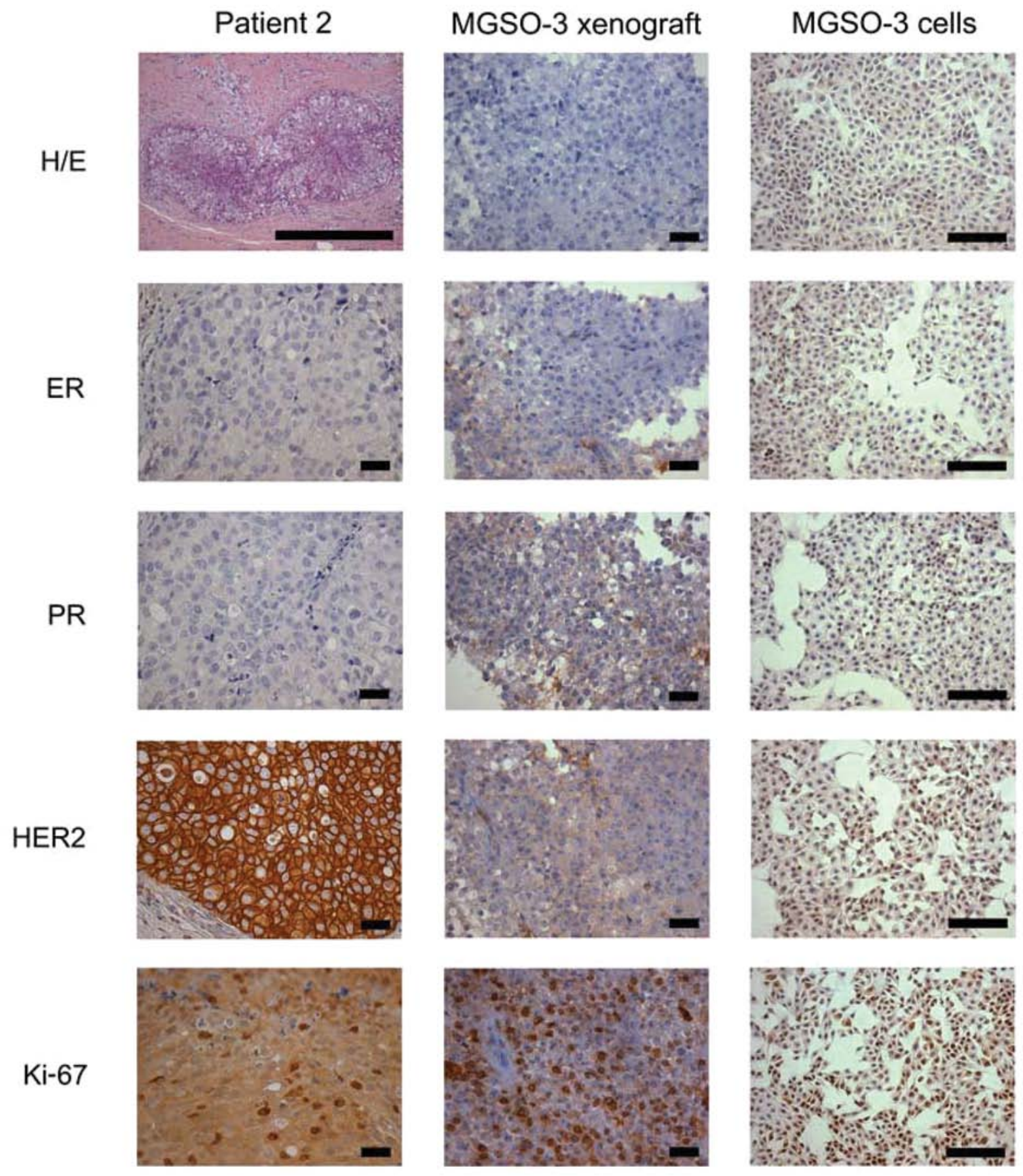

Figure 2. Immunohistochemical profiles of ER, PR, HER2 and Ki-67 markers in the tumor sample from patient 2 (Patient 2); MGSO-3-derived xenograft tumor in immunodeficient mouse (MGSO-3 xenograft) and MGSO-3-cultured cell line (MGSO-3 cells). Scale bar, $100 \mu \mathrm{m}$.
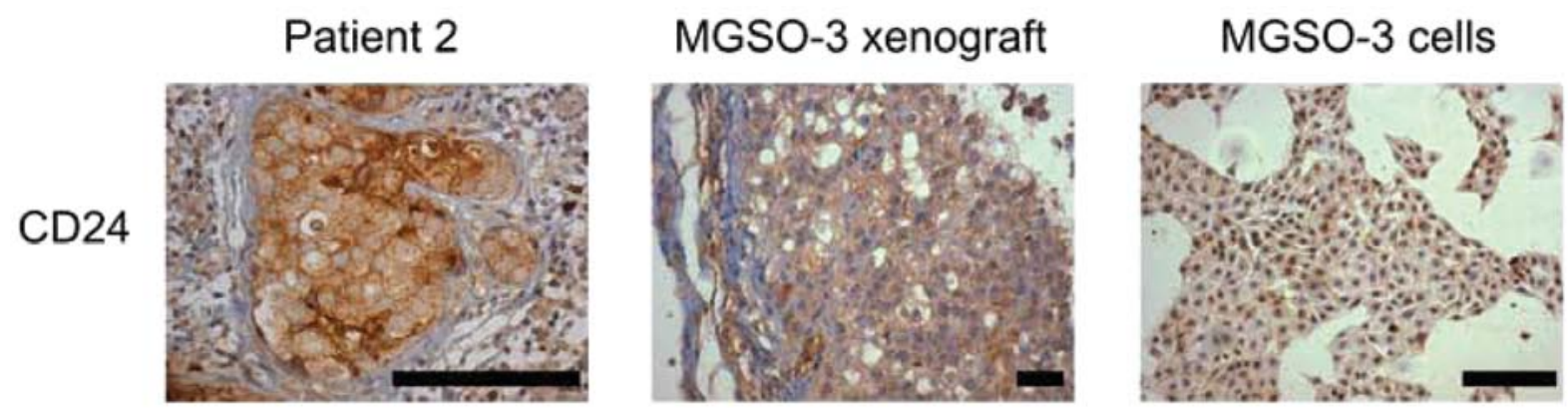

Figure 3. Immunohistochemical staining of CD24 in the tumor sample from patient 2 (Patient 2); MGSO-3-derived xenograft tumor in immunodeficient mouse (MGSO-3 xenograft) and MGSO-3-cultured cell line (MGSO-3 cells). Scale bar, $100 \mu \mathrm{m}$. 
Table III. Main altered genomic regions on MACL-1 and MGSO-3 cell lines, present on the 2 dye swap replicates, with a p-value $<0.05$.

\begin{tabular}{|c|c|c|c|}
\hline Region & Event & Cytoband & Cell line \\
\hline chr17:0-16531500 & Loss & p13.3-p11.2 & MACL-1 \\
\hline chr17:31891535-33317141 & Loss & $\mathrm{q} 12$ & MACL-1 \\
\hline chr17:33661605-36347121 & Loss & $\mathrm{q} 12$ & MACL-1 and MGSO-3 \\
\hline chr17:36548604-38591831 & Loss & $\mathrm{q} 12-\mathrm{q} 21.2$ & MACL-1 and MGSO-3 \\
\hline chr17:38784700-40869210 & Loss & q21.2 & MACL-1 and MGSO-3 \\
\hline chr17:42143048-57671531 & Loss & q21.31-q23.1 & MACL-1 and MGSO-3 \\
\hline chr17:57775091-63421974 & Loss & q23.1-q24.1 & MACL-1 and MGSO-3 \\
\hline chr17:63665720-75057558 & Loss & $\mathrm{q} 24.1-\mathrm{q} 25.2$ & MACL-1 and MGSO-3 \\
\hline chr17:75269931-78653589 & Loss & $\mathrm{q} 25.2-\mathrm{q} 25.3$ & MACL-1 and MGSO-3 \\
\hline chr19:32964337-47953667 & Loss & q13.11-q13.32 & MACL-1 and MGSO-3 \\
\hline chr19:48122394-60078783 & Loss & q13.33-q13.43 & MGSO-3 \\
\hline chr22:17274835-18691763 & Loss & q11.1-q11.21 & MACL-1 and MGSO-3 \\
\hline chr22:20247200-49565875 & Loss & $\mathrm{q} 11.21-\mathrm{q} 13.33$ & MACL-1 and MGSO-3 \\
\hline
\end{tabular}

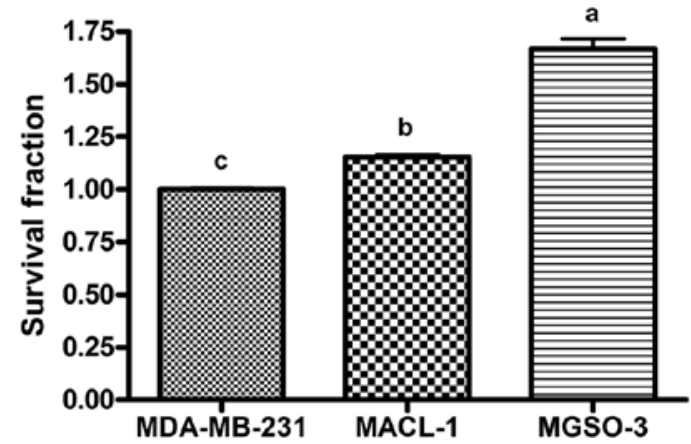

Figure 4. Distinct clonogenic competence of breast cancer cell lines. MACL-1, MGSO-3 and MDA-MB-231 cells were seeded in a $10-\mathrm{cm}^{2}$ dish and incubated for 10 days. Colonies of at least 50 cells were counted as survivors. The mean survival fraction \pm standard error of the mean (SEM) of triplicate wells was normalized to that of MDA-MB 231 cells, based on the extent of plating efficiency. Letters a, b and c assign statistical significant difference (Duncan's post-test, p-value $<0.05$ ).

ated with tumor progression of a more aggressive phenotype, corresponding to its HER2 subtype classification.

Despite displaying a high mitotic index, the MACL-1 and MGSO-3 cells and their derivative tumor xenografts in the immunodeficient mice did not display ER, PR or HER2 staining. The basal phenotype (Ck5 and EGFR) and the breast cancer stem cell markers (CD44, CD24 and CD133) were absent in the primary tumor and cultured cells of patient 1 , as well as the xenografts derived from the 2 cell lines (Table II).

The in vitro establishment of cells derived from primary tumors is a rare event, occurring in relatively few attempts (22) and may thus require selection for an 'in vitro establishment' phenotype (23). It is possible that, as a result of adaptation to a new environment, MACL-1 and MGSO-3 cells shifted to a more appropriate expression pattern for cell culture conditions. Changes in primary tumor markers in the corresponding cultured cell lines have been reported by Brozova et al (24) in breast cancer and by Strojnik et al (25) in glioblastoma.
Differences in the aCGH profiles of breast cancer (26) and the methylation patterns of multiple types of cancer (27) have also been reported in studies comparing cell lines to their respective primary tumors.

Furthermore, the successful transplantation of MACL-1 and MGSO-3 cells into nude mice is noteworthy, since only $7-20 \%$ of these implants are successfully accomplished (28). Specifically, the development of in vivo xenografts of tumor cells allows for the testing of novel therapeutic approaches and the study of local invasion and interaction with stroma (28).

Clonogenic assay. Clonogenic or clonogenic survival assay evaluates the competence of cells to generate a significant number of daughter cells on culture plates after a certain period of time or treatment. The MGSO-3 cell line demonstrated the highest capacity to form colonies after 10 days of incubation, followed by the MACL-1 and MDA-MB-231 lines (Fig. 4). Similar data has been previously reported by Correa et al (11), describing the greater proliferative capability of MGSO-3 when compared to MACL-1 cells using a cell doubling time assessment. Additionally, MGSO-3 tumor xenografts in immunodeficient mice were reported to grow more rapidly compared to MACL-1 tumors (11), and the 2 cell lines demonstrated competence to form tumor-like colonies in soft agar. In a subsequent experiment, MGSO-3 cell lines formed the largest and most numerous colonies that were compatible with xenotransplant and culture growth features (11).

$a C G H$. Subsequent to slide scanning and data extraction using the Feature Extraction software, aCGH data were analyzed using the Nexus Copy Number software. Fig. 5 displays a whole-genome image derived from the analysis and depicts the extensive chromosomal alterations present in the MACL-1 and MGSO-3 cells, a number of them detected on the 2 dye swapped replicates (represented by double-length bars).

The total CNAs attributed to the MACL-1 and MGSO-3 cell lines were $172.5 \pm 30.4$ and $166.5 \pm 12$, respectively. However, 

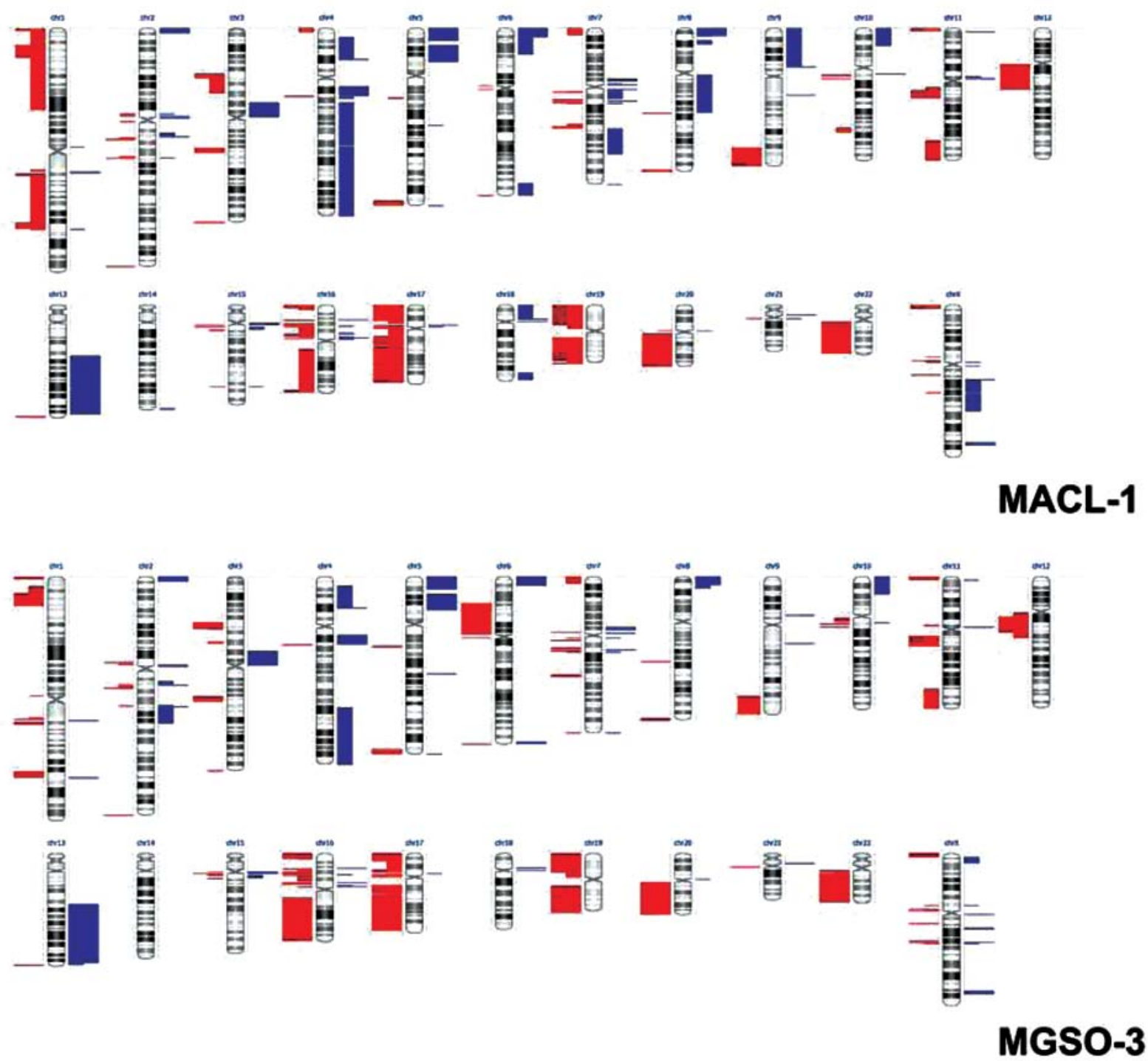

Figure 5. Whole-genome DNA profile of MACL-1 (top panel) and MGSO-3 cells (bottom panel). DNA profiling performed by Human Genome CGH Microarray $4 \times 180 \mathrm{~K}$ platform hybridization showed large chromosomal alterations in both cell lines. The red and blue bars represent losses and gains, respectively. Double-length bars represent alterations detected on the 2 swapping dye replicates.

when only alterations present on the two replicates and with a p-value $<0.05$ are considered, 25 and 33 copy number alterations arise for MACL-1 and MGSO-3, respectively.

The complexity of MACL-1 and MGSO-3 genomes has already been observed by our group when we attempted to explore the karyotype profile of these cells through G-banding or DAPI staining (data not shown). This impairment was promptly demonstrated through our aCGH data, which confirmed extremely complex alterations hindering chromosomal mapping through those techniques. MACL-1 and MGSO-3 cell lines displayed common alterations, such as loss of considerable portions of chromosomes 17, 19 and 22 (Table III). Losses on chromosome 17 took place on the following regions: 17q12, 17q12-q21.2, 17q21.2, 17q21.31-q23.1, 17q23.1-q24.1, 17q24.1q25.2 and 7q25.2-q25.3 (Table III). The MACL-1 and MGSO-3 cells showed significant losses on 17q21.31. Kim et al (29) showed that losses on this region are related to prostate cancer and $17 \mathrm{q} 21.31$ is known to be completely lost in the PC 3 cell line (30). Another important alteration is associated with the 17q12-q21.2 region, where the HER-2 (ERBB2) gene is located.
The loss of this region could explain the lack of HER-2 expression in MGSO-3 cells and derived xenotransplants from this cell line in nude mice.

For chromosome 19 the affected regions were: 19q13.11-q13.32 in the MACL-1 and MGSO-3 cell lines and 19q13.33-q13.43 in the MGSO-3 cell line (Table III). Loss on 19q13.33-13.43 is a rare finding in human tumors, although it has been described in ovarian cancer cells and gliomas $(31,32)$. The loss of heterozigosity on chromosomes in these types of tumor suggests the location of a tumor suppressor gene, but none has yet been found $(31,33,34)$.

Table III also shows alterations on chromosome 22: 22q11.1-q11.21 and 22q11.21-q13.33. Although our previously karyotyping data showed an apparent intact chromosome 22 (data not shown), Table III shows that chromosome 22 exhibited alterations, which are frequently observed in breast carcinomas (35-38). Previous studies have show frequent allelic loss in this region, but similar to $19 \mathrm{q} 13$, a tumor suppressor gene has yet to be confirmed (39). A gene described as important for this region is SMARCB1, also termed IN1. IN1 is consid- 
ered a tumor suppressor gene and was originally identified in malignant rhabdoid tumors of infancy, and subsequently in medullary carcinomas, sarcomas, myoepithelial carcinomas and chondrosarcomas (40).

Overall the biological processes involved in MACL-1 and MGSO-3 CNAs showed alterations in genes that are engaged in several activities including gene transcription and regulation, cell cycle, signal transduction and metabolic processes. As expected there does not appear to be a concise bias toward a particular biological process.

In conclusion, MACL-1 and MGSO-3 cell lines changed their protein expression profile possibly due to a selection pressure for a more fitted phenotype on cell culture conditions. This phenotypic shift was conserved in tumor xenografts in immunodeficient mice. Despite carrying extensive chromosomal imbalances, these cells maintained a high proliferative ability. To the best of our knowledge, MACL-1 and MGSO-3 are the only Brazilian breast cancer cell lines that could be used for comparative studies with other known breast cancer cell lines.

\section{Acknowledgements}

This study was supported by the National Institutes of Health (NIH; grant no. 1R03TW008709) and by grants from the Fundação de Amparo à Pesquisa do Estado de Minas Gerais (FAPEMIG), Coordenação de Aperfeiçoamento de Pessoal de Nível Superior (CAPES) and Conselho Nacional de Desenvolvimento Científico e Tecnológico (CNPq). The authors are thankful for the financial support provided by Pró-Reitoria de Pesquisa da Universidade Federal de Minas Gerais.

\section{References}

1. INCA: Estimativa 2012: Incidência de câncer no Brasil. Instituto Nacional de Câncer José Alencar Gomes da Silva, Coordenação Geral de Ações Estratégicas, Coordenação de Prevenção e Vigilância. Rio de Janeiro, p188, 2011.

2. Hammond ME, Hayes DF, Dowsett M, Allred DC, Hagerty KL Badve S, et al: American Society of Clinical Oncology/College of American Pathologists guideline recommendations for immunohistochemical testing of estrogen and progesterone receptors in breast cancer (unabridged version). Arch Pathol Lab Med 134 e48-e72, 2010

3. Wolff AC, Hammond ME, Schwartz JN, Hagerty KL, Allred DC, Cote RJ, et al: American Society of Clinical Oncology/College of American Pathologists guideline recommendations for human epidermal growth factor receptor 2 testing in breast cancer. Arch Pathol Lab Med 131: 18-43, 2007.

4. Goldhirsch A, Ingle JN, Gelber RD, Coates AS, Thurlimann B and Senn HJ: Thresholds for therapies: highlights of the St Gallen International Expert Consensus on the primary therapy of early breast cancer. Ann Oncol 20: 1319-1329, 2009.

5. Perou CM, Sorlie T, Eisen MB, van de RM, Jeffrey SS, Rees CA, et al: Molecular portraits of human breast tumours. Nature 406: 747-752, 2000.

6. Sorlie T, Perou CM, Tibshirani R, Aas T, Geisler S, Johnsen $\mathrm{H}$, et al: Gene expression patterns of breast carcinomas distinguish tumor subclasses with clinical implications. Proc Natl Acad Sci USA 98: 10869-10874, 2001.

7. Sorlie T, Perou CM, Fan C, Geisler S, Aas T, Nobel A, et al: Gene expression profiles do not consistently predict the clinical treatment response in locally advanced breast cancer. Mol Cancer Ther 5: 2914-2918, 2006.

8. Sorlie T, Tibshirani R, Parker J, Hastie T, Marron JS, Nobel A, et al: Repeated observation of breast tumor subtypes in independent gene expression data sets. Proc Natl Acad Sci USA 100: 8418-8423, 2003.
9. Prat A, Parker JS, Karginova O, Fan C, Livasy C, Herschkowitz JI, et al: Phenotypic and molecular characterization of the claudin-low intrinsic subtype of breast cancer. Breast Cancer Res 12: R68, 2010.

10. Kao J, Salari K, Bocanegra M, Choi YL, Girard L, Gandhi J, et al: Molecular profiling of breast cancer cell lines defines relevant tumor models and provides a resource for cancer gene discovery. PLoS One 4: e6146, 2009.

11. Correa CR, Bertollo CM and Goes AM: Establishment and characterization of MACL-1 and MGSO-3 cell lines derived from human primary breast cancer. Oncol Res 17: 473-482, 2009.

12. Correa CR, Bertollo CM, Zouain CS and Goes AM: Glyceraldehyde-3-phosphate dehydrogenase as a surface associated antigen on human breast cancer cell lines MACL-1 and MGSO-3. Oncol Rep 24: 677-685, 2010.

13. Bertollo CM, Correa CR, Gomes DA, Souza-Fagundes EM and Goes AM: Effect of radiation treatment on newly established human breast cancer cell lines MACL-1 and MGSO-3. Tumour Biol 31: 189-197, 2010.

14. Yerushalmi R, Woods R, Ravdin PM, Hayes MM and Gelmon KA: Ki67 in breast cancer: prognostic and predictive potential. Lancet Oncol 11: 174-183, 2010.

15. Al Hajj M, Wicha MS, Benito-Hernandez A, Morrison SJ and Clarke MF: Prospective identification of tumorigenic breast cancer cells. Proc Natl Acad Sci USA 100: 3983-3988, 2003.

16. Wright MH, Calcagno AM, Salcido CD, Carlson MD, Ambudkar SV and Varticovski L: Brcal breast tumors contain distinct $\mathrm{CD}^{-} 4^{+} / \mathrm{CD} 24^{-}$and $\mathrm{CD} 133^{+}$cells with cancer stem cell characteristics. Breast Cancer Res 10: R10, 2008.

17. Franken NA, Rodermond HM, Stap J, Haveman J and van Bree C: Clonogenic assay of cells in vitro. Nat Protoc 1: 2315-2319, 2006.

18. Sambrook J and Russel DW: Isolation of High-molecular-weight DNA from mammalian cells using proteinase $\mathrm{K}$ and phenol. In: Molecular Cloning: A Laboratory Manual. Cold Spring Harbor Laboratory Press, Cold Spring Harbor, NY, 2001.

19. Lim SC: CD24 and human carcinoma: tumor biological aspects. Biomed Pharmacother 59 (Suppl 2): S351-S354, 2005.

20. Baumann P,Cremers N,Kroese F, Orend G, Chiquet-Ehrismann R, Uede T, et al: CD24 expression causes the acquisition of multiple cellular properties associated with tumor growth and metastasis. Cancer Res 65: 10783-10793, 2005.

21. Kristiansen G, Sammar M and Altevogt P: Tumour biological aspects of CD24, a mucin-like adhesion molecule. J Mol Histol 35: 255-262, 2004.

22. O'Hare MJ: Breast cancer. In: Human Cancer in Primary Culture, A Handbook. Masters JRW (ed). Kluwer Academic Publishers, London, pp271-286, 1991

23. Kim JB, O'Hare MJ and Stein R: Models of breast cancer: is merging human and animal models the future? Breast Cancer Res 6: 22-30, 2004.

24. Brozova M, Kleibl Z, Netikova I, Sevcik J, Scholzova E, Brezinova $\mathbf{J}$, et al: Establishment, growth and in vivo differentiation of a new clonal human cell line, EM-G3, derived from breast cancer progenitors. Breast Cancer Res Treat 103: 247-257, 2007.

25. Strojnik T, Kavalar R, Barone TA and Plunkett RJ: Experimental model and immunohistochemical comparison of U87 human glioblastoma cell xenografts on the chicken chorioallantoic membrane and in rat brains. Anticancer Res 30: 4851-4860, 2010.

26. Tsuji K, Kawauchi S, Saito S, Furuya T, Ikemoto K, Nakao M, et al: Breast cancer cell lines carry cell line-specific genomic alterations that are distinct from aberrations in breast cancer tissues: comparison of the $\mathrm{CGH}$ profiles between cancer cell lines and primary cancer tissues. BMC Cancer 10: 15, 2010

27. Smiraglia DJ, Rush LJ, Fruhwald MC, Dai Z, Held WA, Costello JF, et al: Excessive CpG island hypermethylation in cancer cell lines versus primary human malignancies. Hum Mol Genet 10: 1413-1419, 2001.

28. Vargo-Gogola T and Rosen JM: Modelling breast cancer: one size does not fit all. Nat Rev Cancer 7: 659-672, 2007.

29. Kim JH, Dhanasekaran SM, Mehra R, Tomlins SA, Gu W, $\mathrm{Yu}$ J, et al: Integrative analysis of genomic aberrations associated with prostate cancer progression. Cancer Res 67: 8229-8239, 2007.

30. Clark J, Edwards S, Feber A, Flohr P, John M, Giddings I, et al: Genome-wide screening for complete genetic loss in prostate cancer by comparative hybridization onto cDNA microarrays. Oncogene 22: 1247-1252, 2003. 
31. Mora J, Cheung NK, Chen L, Qin J and Gerald W: Loss of heterozygosity at $19 \mathrm{q} 13.3$ is associated with locally aggressive neuroblastoma. Clin Cancer Res 7: 1358-1361, 2001.

32. Barbashina V, Salazar P, Holland EC, Rosenblum MK and Ladanyi M: Allelic losses at 1p36 and 19q13 in gliomas: correlation with histologic classification, definition of a $150-\mathrm{kb}$ minimal deleted region on 1p36, and evaluation of CAMTA1 as a candidate tumor suppressor gene. Clin Cancer Res 11: 1119$1128,2005$.

33. Chou D, Miyashita T, Mohrenweiser HW, Ueki K, Kastury K, Druck T, et al: The BAX gene maps to the glioma candidate region at $19 \mathrm{q} 13.3$, but is not altered in human gliomas. Cancer Genet Cytogenet 88: 136-140, 1996.

34. Smith JS, Tachibana I, Pohl U, Lee HK, Thanarajasingam U, Portier BP, et al: A transcript map of the chromosome 19q-arm glioma tumor suppressor region. Genomics 64: 44-50, 2000.

35. Iida $A$, Kurose $K$, Isobe $R$, Akiyama $F$, Sakamoto $G$, Yoshimoto M, et al: Mapping of a new target region of allelic loss to a 2-cM interval at 22q13.1 in primary breast cancer. Genes Chromosomes Cancer 21: 108-112, 1998.
36. Bieche I and Lidereau R: Genetic alterations in breast cancer. Genes Chromosomes Cancer 14: 227-251, 1995.

37. Sato T, Tanigami A, Yamakawa K, Akiyama F, Kasumi F, Sakamoto G and Nakamura Y: Allelotype of breast cancer: cumulative allele losses promote tumor progression in primary breast cancer. Cancer Res 50: 7184-7189, 1990.

38. Allione F, Eisinger F, Parc P, Noguchi T, Sobol H and Birnbaum D: Loss of heterozygosity at loci from chromosome arm 22Q in human sporadic breast carcinomas. Int J Cancer 75: 181-186, 1998.

39. Benetkiewicz M, Piotrowski A, Díaz De Ståhl T, Jankowski M, Bala D, Hoffman J, et al: Chromosome 22 array-CGH profiling of breast cancer delimited minimal common regions of genomic imbalances and revealed frequent intra-tumoral genetic heterogeneity. Int J Oncol 29: 935-945, 2006.

40. Hollmann TJ and Hornick JL: INI1-deficient tumors: diagnostic features and molecular genetics. Am J Surg Pathol 35: e47-e63, 2011. 